\title{
The design, optimisation, and use of the seismic system at the deep and high-stress block cave Deep Mill Level Zone mine
}

W de Beer ESG Solutions, Australia

A Jalbout Goldcorp, Canada

E Riyanto PT Freeport Indonesia, Indonesia

A Ginting PT Freeport Indonesia, Indonesia

M Sullivan PT Freeport Indonesia, Indonesia

DS Collins ESG Solutions, Canada

\begin{abstract}
The PT Freeport Indonesia Grasberg mine in Papua, Indonesia is composed of the Grasberg open pit and four underground mine operations. The Deep Mill Level Zone (DMLZ) is one of the currently active block cave underground operations. The DMLZ orebody presents a number of significant engineering challenges and technical risks when compared to other operating block caves. Due to its mining method and the depth of the operation $(+1,500 \mathrm{~m})$, mining-induced seismicity was identified as one of the key factors that will affect the rock mass stability. The seismic system is one of the main tools that is used to track and understand the rock mass response for this cave propagation.
\end{abstract}

This paper presents initial results from the DMLZ, and includes details about the rock properties, seismic system optimisation using blast data, and seismic analysis examples to help aid in the safety and productivity of the block cave operation.

Keywords: microseismic, monitoring, block caving, system, optimisation, seismicity

\section{Introduction}

PT Freeport Indonesia's (PTFI) Grasberg mine is located in the Sudirman Mountains at an elevation of 3,000 to $4,500 \mathrm{~m}$ above sea level (Figure 1). The mine complex produces about 250,000 tonnes per day of material from Grasberg open pit, and four other active underground operations and projects under construction, i.e. Deep Ore Zone (DOZ), Big Gossan (BG), Grasberg Block Cave (GBC) and the Deep Mill Level Zone (DMLZ). The mine complex produces mainly copper and gold.

The DMLZ mine is the fourth lift of caving in the East Ertsberg Skarn System (EESS) and lies $500 \mathrm{~m}$ below the currently producing mine (DOZ) and approximately $2,000 \mathrm{~m}$ below surface. There is approximately $1,500 \mathrm{~m}$ of caved material above the mine (Figure 2). The DMLZ mine represents about a half billion tonnes of ore and there are around 2,450 drawpoints planned, with the scheduled daily tonnage planned to peak at around 80,000 tonnes per day. Grades are $0.87 \%$ copper and $0.71 \mathrm{~g} / \mathrm{t}$ gold. The mine life is projected through to 2041 , and at full production the DMLZ will have around 700 active drawpoints in operation at any given time (Casten et al. 2016).

This paper starts with a summary section on the main geology and rock properties of the DMLZ, followed by sections on the seismic system assessment after installation, and seismic analysis examples that are being used to help maintain the safety and productivity of the mine operation. 


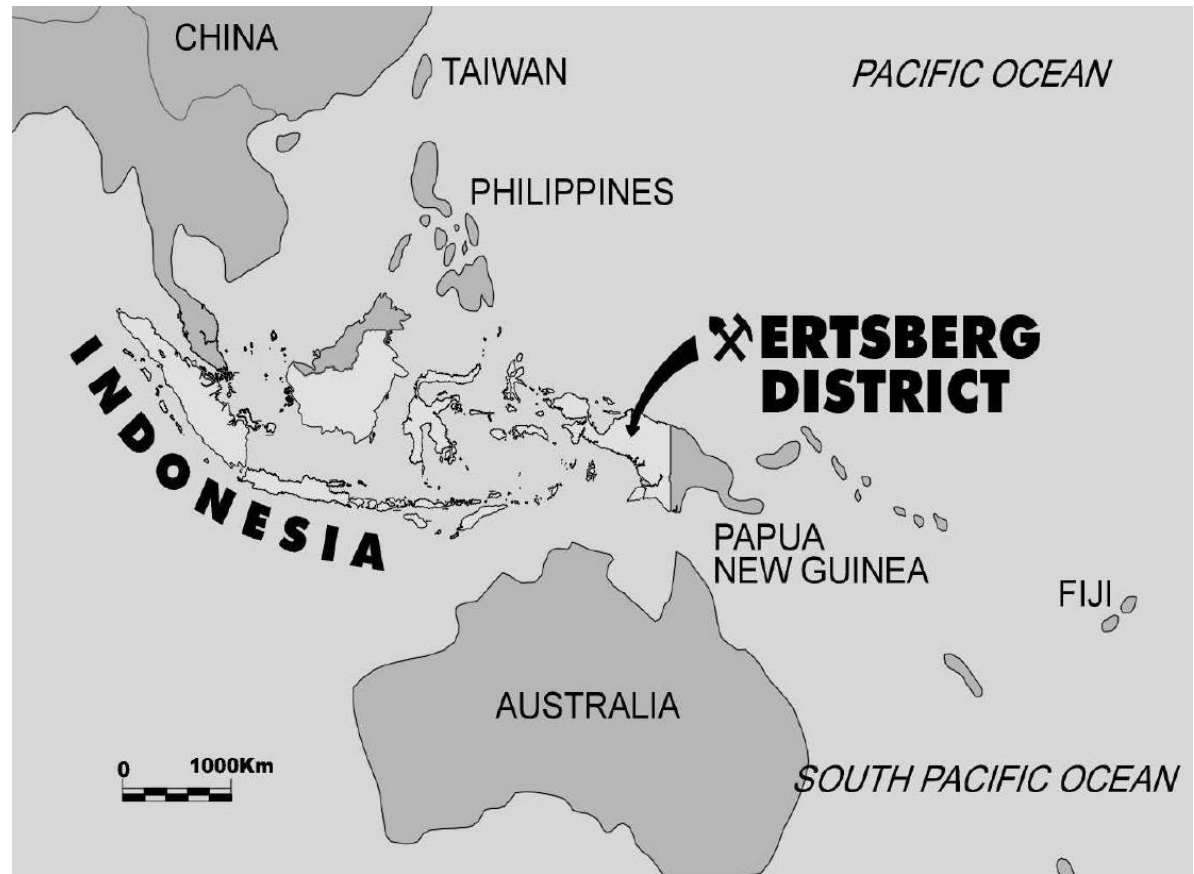

Figure 1 Location of PT Freeport Indonesia operations (Kurniawan et al. 2016)

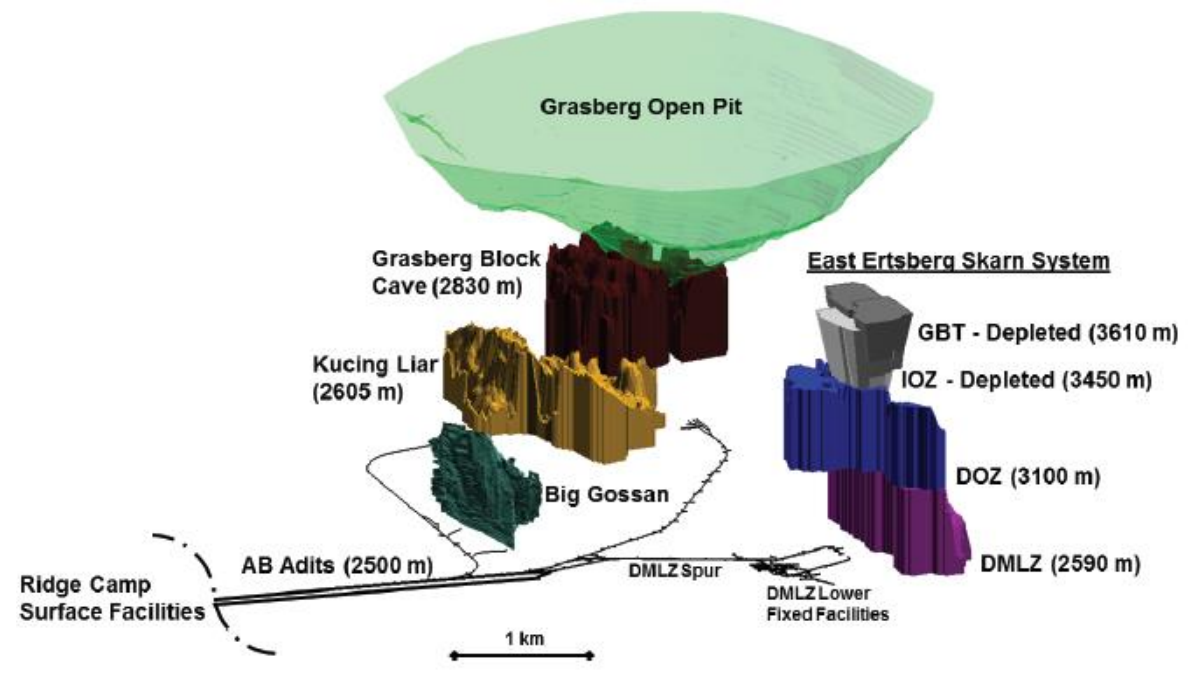

Figure 2 Freeport Indonesia orebodies and primary AB Adit (Ali Budiardjo Adit for access tunnel to DMLZ, GBC and Big Gossan) access (Casten et al. 2016)

\section{Geology}

The geology of the DMLZ extraction level is illustrated in Figure 3. Principal geological units are the Ertsberg diorite, Waripi and Kembelagan limestones, and skarns located at the diorite contact. Major structures include several splays of the northwest trending faults. 


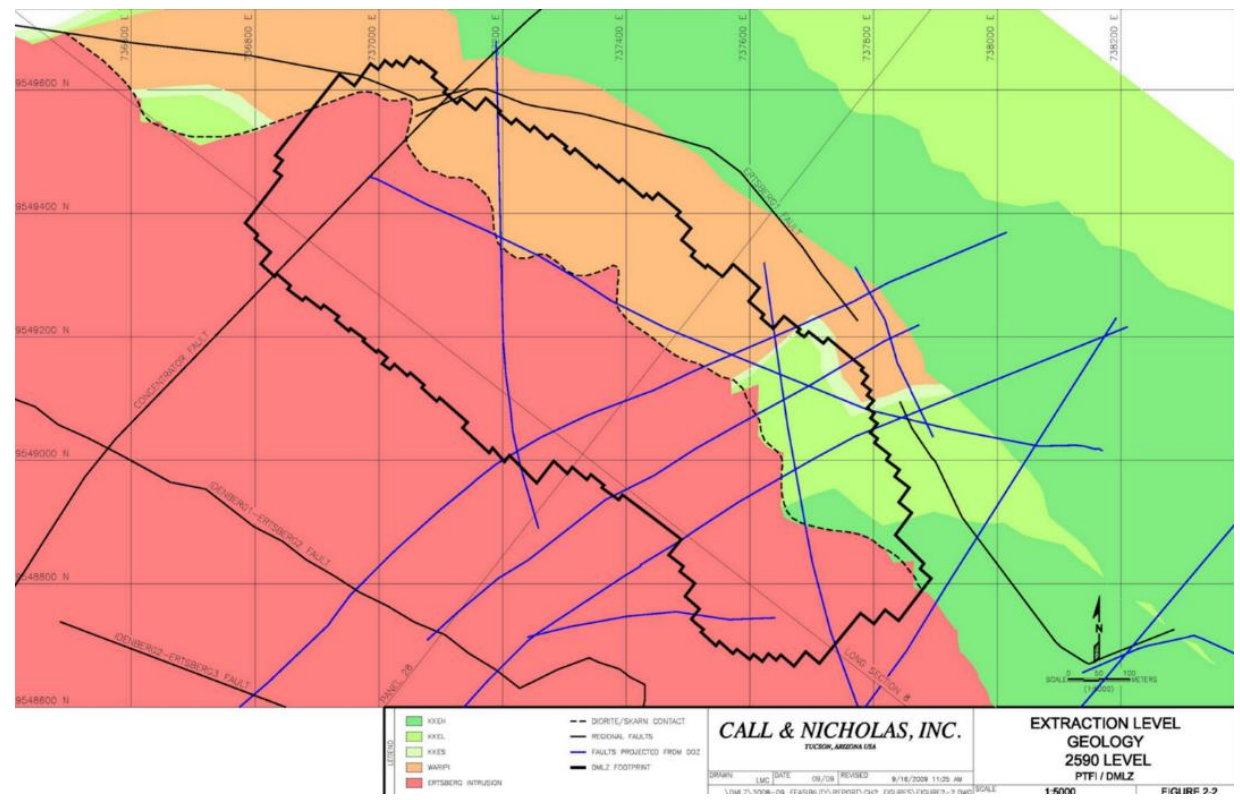

Figure 3 The geology of the extraction level (Call \& Nicholas, Inc. 2009)

\subsection{Major structure and rock mass characterisation}

Figure 4 illustrates the geology along DMLZ panel drift 28. In addition to the steeply dipping Idenberg and Ertsberg Faults, the Yellow Valley Syncline is illustrated to the north of the GBC, IOZ, DOZ, and DMLZ. Skarns are the predominant unit in contact with the Ertsberg diorite. The rock mass strengths used in this study are summarised in Tables 1 and 2 (Call \& Nicholas, Inc. 2009).

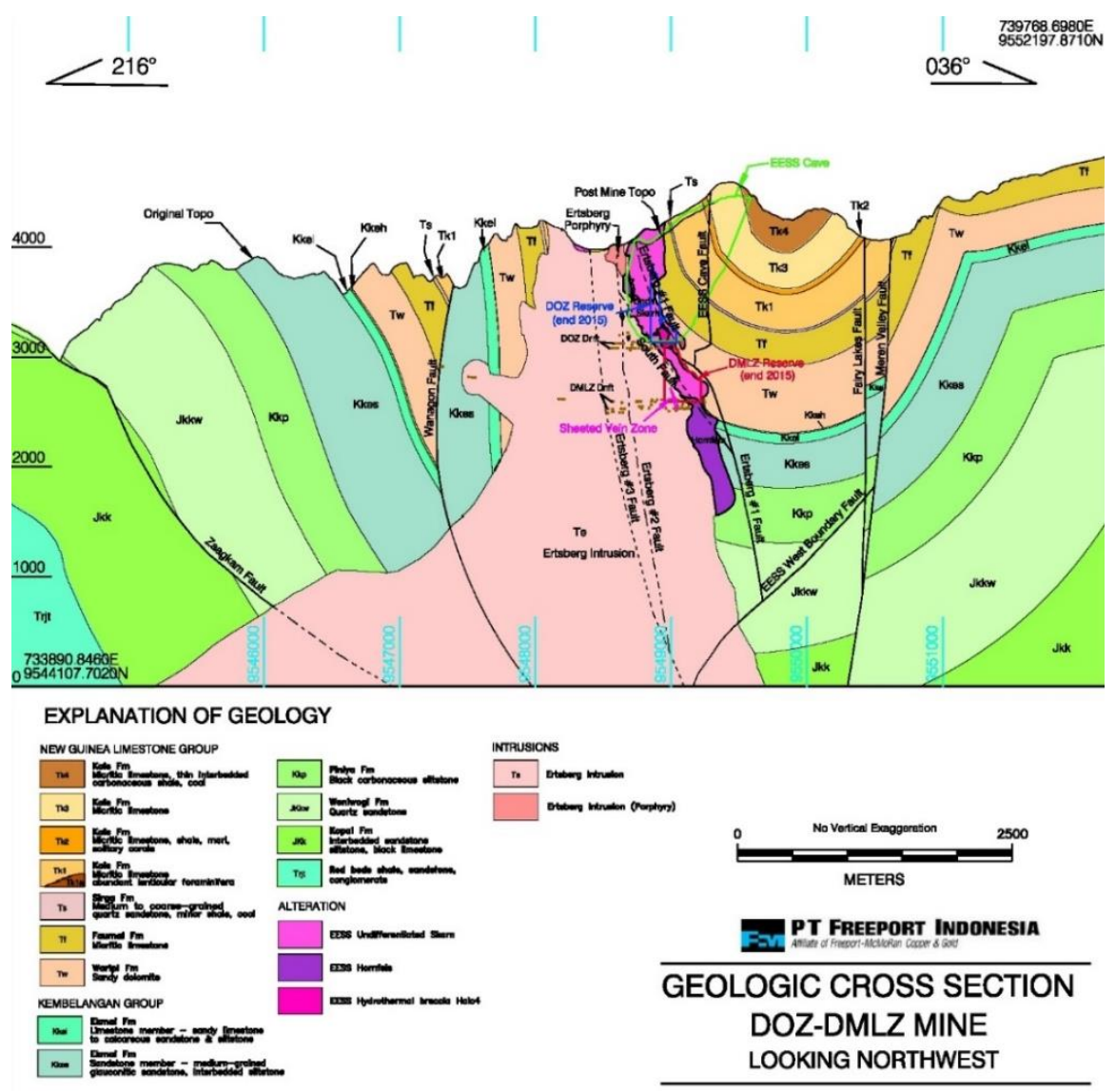

Figure 4 Geology cross-section in DMLZ mine - section looking northwest (P. Warren, pers. comm., June 2017) 
Table 1 Intact material properties summary

\begin{tabular}{|c|c|c|c|c|c|c|c|c|}
\hline \multirow[t]{2}{*}{ Rock type } & \multicolumn{2}{|c|}{$\begin{array}{l}\text { Uniaxial compressive } \\
\text { strength (UCS) }\end{array}$} & \multicolumn{2}{|c|}{ Tensile strength } & \multicolumn{4}{|l|}{ Density } \\
\hline & $\begin{array}{l}\text { Average } \\
\text { (MPa) }\end{array}$ & $\begin{array}{l}\text { Standard } \\
\text { deviation } \\
\text { (MPa) }\end{array}$ & $\begin{array}{l}\text { Average } \\
\text { (MPa) }\end{array}$ & $\begin{array}{l}\text { Standard } \\
\text { deviation } \\
\text { (MPa) }\end{array}$ & $\begin{array}{l}\text { Average } \\
\left(\mathrm{kg} / \mathrm{m}^{3}\right)\end{array}$ & $\begin{array}{l}\text { Standard } \\
\text { deviation } \\
\left(\mathrm{kg} / \mathrm{m}^{3}\right)\end{array}$ & $\begin{array}{l}E \\
(\mathrm{GPa})\end{array}$ & $\mathbf{v}$ \\
\hline Limestone & 141 & 59 & 9.9 & 3.3 & 2,850 & 145 & 64 & 0.30 \\
\hline Skarn & 120 & 55 & 11.2 & 4.2 & 3,458 & 662 & 75 & 0.30 \\
\hline Diorite & 157 & 39 & 11.5 & 2.1 & 2,704 & 184 & 52 & 0.30 \\
\hline
\end{tabular}

Table 2 Intact cohesion and friction angles for DMLZ rock types

\begin{tabular}{lll}
\hline Rock type & Friction angle & Cohesion (MPa) \\
\hline Limestone & 45.6 & 30.7 \\
Skarn & 49.3 & 8.2 \\
Diorite & 48.4 & 30.9 \\
\hline
\end{tabular}

\section{Seismic system array}

\subsection{Summary}

The seismic array comprises of a mixture of uniaxial and triaxial $15-\mathrm{Hz}$ geophones installed in boreholes ranging from short $10 \mathrm{~m}$ upholes to longer downholes up to $600 \mathrm{~m}$ in length. The sensor spacing is purposely more dense around the expected cave development in order to provide more accuracy and sensitivity in this region. A few of the sensors above the cave zone are sacrificial.

\subsection{Seismic array site optimisation}

To date, two array optimisations have been performed. In June 2016 a single velocity model (termed here 1DVM) was established using ten drawbell blasts with known locations (Figure 5), and in March 2017 a mesoscale, semi-static velocity model which incorporates gross geology and the cave outline (termed here 3DVM (Collins et al. 2014; Pinnock et al. 2016) was derived using oriented sensors and known geological domains and excavations (Figure 6). Blast locations were determined on mine plans to within $5 \mathrm{~m}$ of the centre position of a planned blast volume. The optimal 1DVM in 2016 was found to be $V_{P}=5,710 \mathrm{~m} \cdot \mathrm{s}^{-1}$ and $V_{S}=3,240 \mathrm{~m} \cdot \mathrm{s}^{-1}$, where $V_{P / S}$ is the P-wave/S-wave velocity, respectively. Table 3 displays the absolute location trueness of the ten blasts used. Overall, the root mean square (RMS) location trueness (Equation 1) was $26.6 \mathrm{~m}$, with a slight bias to the north. Note that real events in which S-waves can be identified are expected to have improved accuracy.

$$
R M S=\sqrt{\frac{\sum_{1}^{n} \text { difference }^{2}}{n}}
$$

The March 2017 3DVM was built using eleven blasts with clear signals (Figure 7). These were production (DMLZ) or secondary breaking (DOZ) blasts which could be identified with a fair degree of confidence. The results are shown in Table 4.

It is expected that location accuracy will decrease as the cave zone develops in size (some sensors will be lost) and the rock mass becomes more attenuating. Installation of additional uniaxial geophone sensors are planned in specific regions around the cave to help improve location accuracy over time. The 3DVM will be regularly updated as the cave zone develops upwards and outwards. 


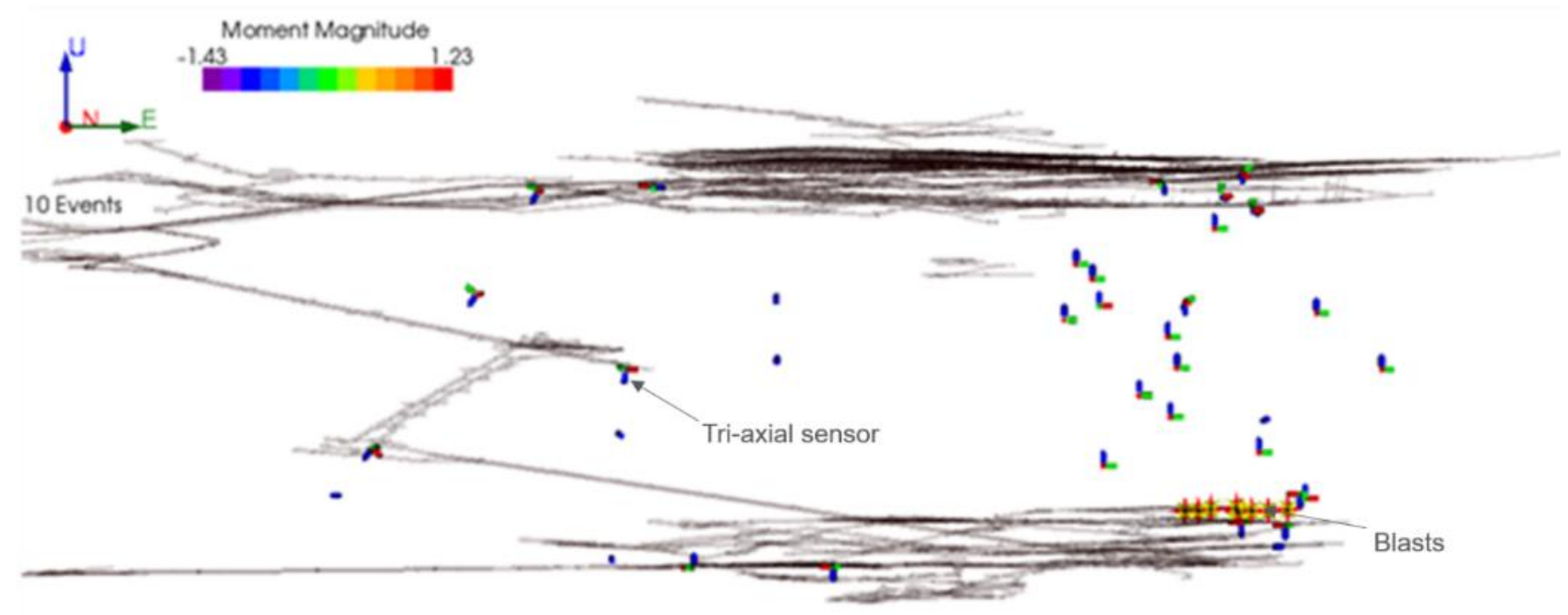

Figure 5 Location of the working sensors and ten blasts used for site optimisation in June 2016. The blasts are all near to the initial cave development providing a good estimate of the absolute location accuracy in this area

Table 3 Quantification of the location trueness using blast data at the site (2016)

\begin{tabular}{|c|c|c|c|c|c|c|c|c|c|c|c|}
\hline \multirow[b]{2}{*}{ Date } & \multirow[b]{2}{*}{ Time } & \multicolumn{3}{|c|}{ Known coordinates (m) } & \multicolumn{3}{|c|}{ Calculated coordinates $(\mathrm{m})$} & \multicolumn{3}{|c|}{$\begin{array}{l}\text { Difference (known - } \\
\text { calculated) }(\mathrm{m})\end{array}$} & \multirow[b]{2}{*}{ Distance } \\
\hline & & North & East & Elevation & North & East & Elevation & North & East & Elevation & \\
\hline $02 \mathrm{Apr} 16$ & $17: 16: 26$ & 9549201 & 737622 & 2612.1 & 9549186 & 737617 & 2609.9 & 15.3 & 5.6 & 2.2 & 16.4 \\
\hline 02 Apr 16 & $17: 16: 26$ & 9549162 & 737554 & 2608.1 & 9549145 & 737558 & 2619 & 17 & -4.1 & -10.9 & 20.6 \\
\hline 04 Apr 16 & 17:03:07 & 9549159 & 737551 & 2608.1 & 9549148 & 737553 & 2630.3 & 11 & -1.8 & -22.2 & 24.8 \\
\hline 04 Apr 16 & 17:03:07 & 9549148 & 737505 & 2612.3 & 9549137 & 737508 & 2624.1 & 11.4 & -3.8 & -11.8 & 16.8 \\
\hline $07 \mathrm{Apr} 16$ & $17: 47: 25$ & 9549164 & 737592 & 2609.4 & 9549142 & 737611 & 2630.4 & 21.6 & -18.5 & -21 & 35.4 \\
\hline 07 Apr 16 & $17: 58: 14$ & 9549147 & 737485 & 2609.4 & 9549130 & 737472 & 2603.9 & 17.3 & 12.4 & 5.5 & 22 \\
\hline 07 Apr 16 & 17:30:14 & 9549153 & 737546 & 2608.1 & 9549138 & 737555 & 2633.5 & 14.7 & -9 & -25.4 & 30.7 \\
\hline 08 Apr 16 & $17: 30: 15$ & 9549146 & 737465 & 2609.4 & 9549137 & 737479 & 2628.9 & 9.4 & -14.2 & -19.5 & 25.9 \\
\hline 08 Apr 16 & $17: 53: 00$ & 9549155 & 737567 & 2609.4 & 9549121 & 737546 & 2598.7 & 33.5 & 20.3 & 10.7 & 40.6 \\
\hline \multirow[t]{2}{*}{18 Apr 16} & $17: 29: 56$ & 9549149 & 737543 & 2613.9 & 9549139 & 737543 & 2634.8 & 10.3 & 0.5 & -20.9 & 23.3 \\
\hline & & & & & & & RMS: & 17.5 & 11.2 & 16.7 & 26.6 \\
\hline
\end{tabular}




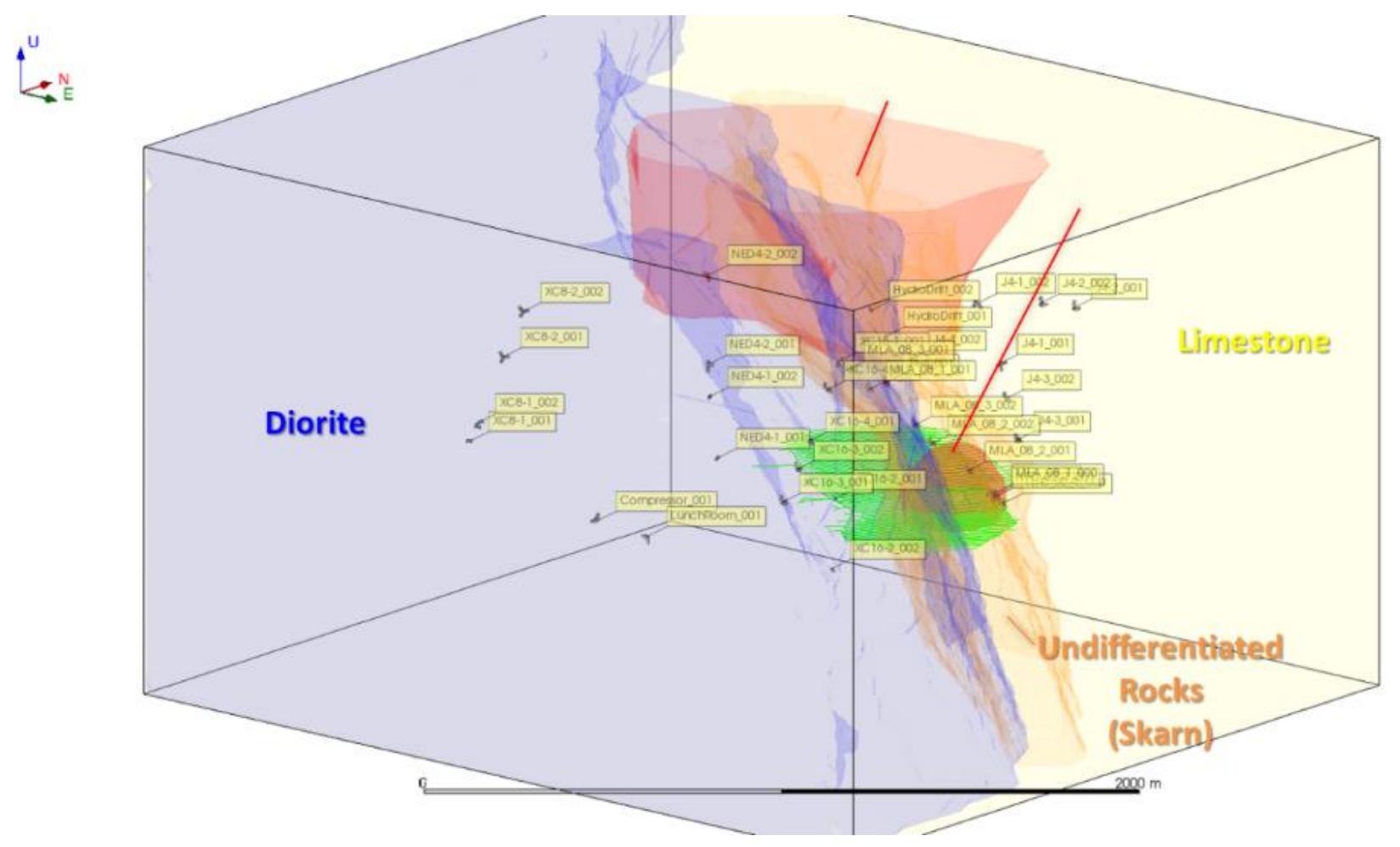

Figure 6 Geological domains and alterations to the rock mass by mining effecting the velocity structure used in the March 2017 3DVM construction

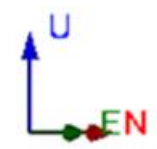

11 Events Selected

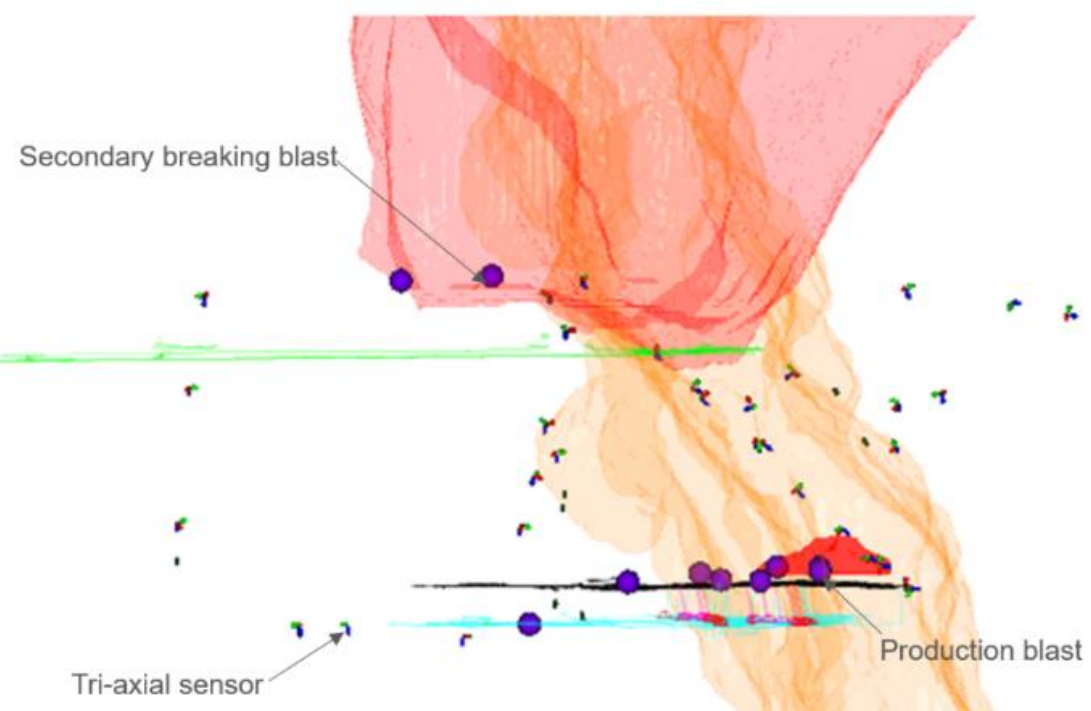

Figure 7 Blasts and sensors used in March 2017 3DVM construction 
Table 4 Average seismic velocities in the four identified mesoscale domain at the DMLZ mine

\begin{tabular}{|c|c|c|c|}
\hline Domain & $V_{P}\left(\mathrm{~m} \mathrm{~s}^{-1}\right)$ & $V_{s}\left(\mathrm{~m} \mathrm{~s}^{-1}\right)$ & Comment \\
\hline \multirow{2}{*}{ Diorite } & \multirow{2}{*}{5,590} & \multirow{2}{*}{3,175} & $V_{P}$ estimated using calibration blasts \\
\hline & & & $V_{s}$ estimated using calibration blasts \\
\hline \multirow{2}{*}{ Limestone } & \multirow{2}{*}{4,910} & \multirow{2}{*}{2,840} & $V_{P}$ estimated using calibration blasts \\
\hline & & & $V_{s}$ estimated assuming Poisson's ratio $=0.25$ \\
\hline \multirow{2}{*}{$\begin{array}{l}\text { Undifferentiated } \\
\text { rocks (skarn) }\end{array}$} & \multirow{2}{*}{6,225} & \multirow{2}{*}{3,450} & $V_{P}$ estimated using calibration blasts \\
\hline & & & $V_{s}$ estimated using calibration blasts \\
\hline \multirow{2}{*}{ Caves (filled) } & \multirow{2}{*}{3,110} & \multirow{2}{*}{1,725} & $V_{P}$ estimated to be $50 \%$ of skarn vel \\
\hline & & & $V_{s}$ estimated to be $50 \%$ of skarn vel \\
\hline
\end{tabular}

\section{$4 \quad$ Rock mass seismic response}

\subsection{Introduction}

The DMLZ is a seismically active mining area. The microseismic monitoring system can detect events down to moment magnitude $M_{w}=-2.1$, while there is a substantial population of events larger than $M_{w}=0.0$ (Figure 8). Note that, since the dataset represented in Figure 8 was acquired, an event of $M_{w}=2.25$ has occurred. The seismic system at the DMLZ currently consists of $15-\mathrm{Hz}$ geophone sensors. A few lower frequency $4.5-\mathrm{Hz}$ geophones are planned to be installed in the near future to help improve the accuracy of seismic source parameters of larger magnitude events. The DMLZ mine staff are developing a plan to manage the hazard associated with mining in high-stress ground. The analysis is in early stages, and starts with the spatial distribution of seismicity, followed by relating events magnitudes and distances from damage. Different seismic source parameters are being analysed (seismic moment, seismic energy and apparent volume). This section focuses on three aspects: zonation, significant events, and ground motion.

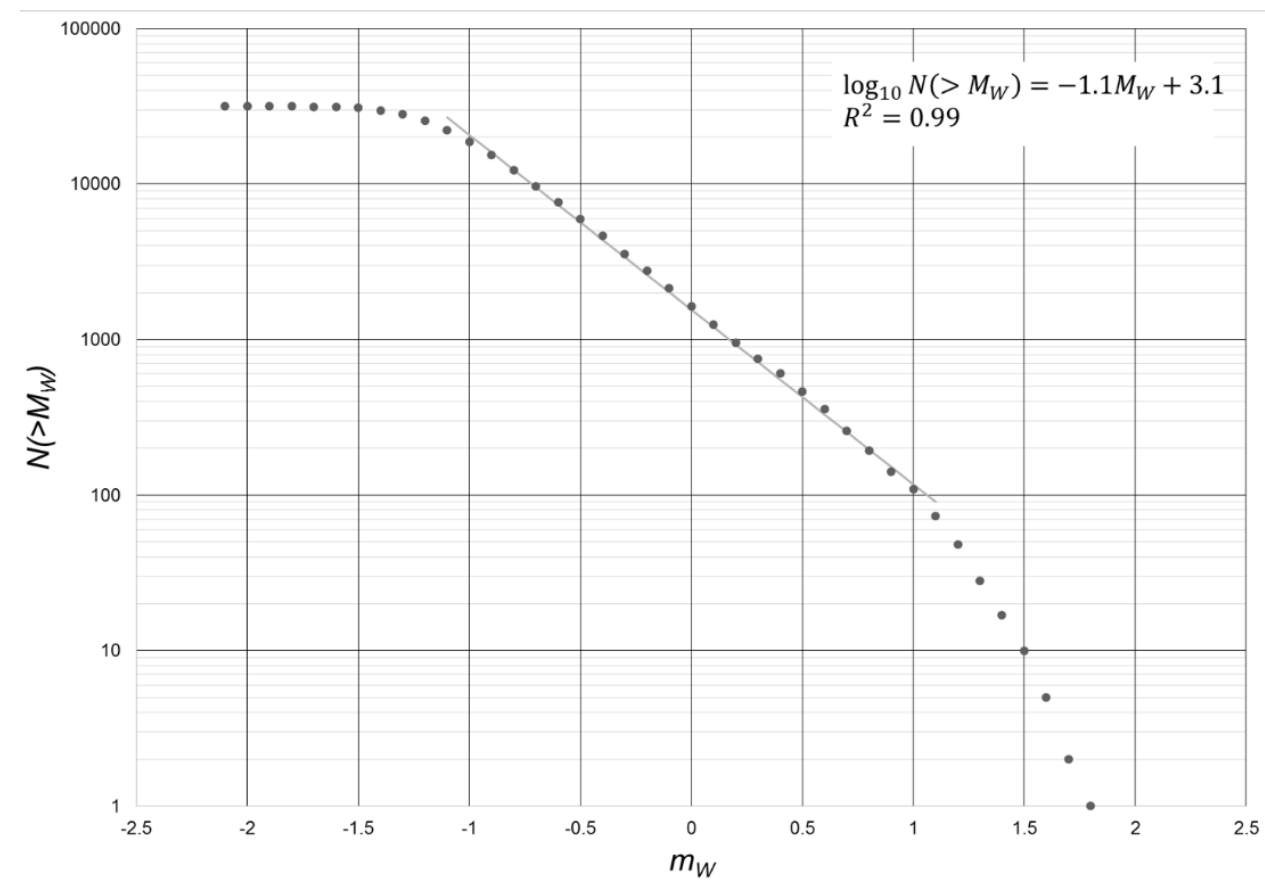

Figure 8 Complimentary cumulative magnitude frequency plot for events in the DMLZ, March 2016 to early October 2016 


\subsection{Zonation}

Periodic snapshots of seismicity (Figure 9) reveal a halo of seismic activity propagating in advance of the undercut face. This halo is variously termed the 'zone of influence of the cave', the 'cave zone', or the 'seismogenic zone'. Unfortunately, this is also the area where people work, requiring a management tool to aid in deciding when and where work can take place. The area is characterised in space and time by dividing it into zones. Zones are characterised by the amount of seismicity, degree of damage (as a proxy for susceptibility to damage - see Figure 10), times of increased hazard (Figure 11), and distance from seismicity (Figure 12). The footprint around and below the current cave may then be divided into different zones (Figure 13), where a 'red zone' would be a no-go zone during a particular exclusion period.

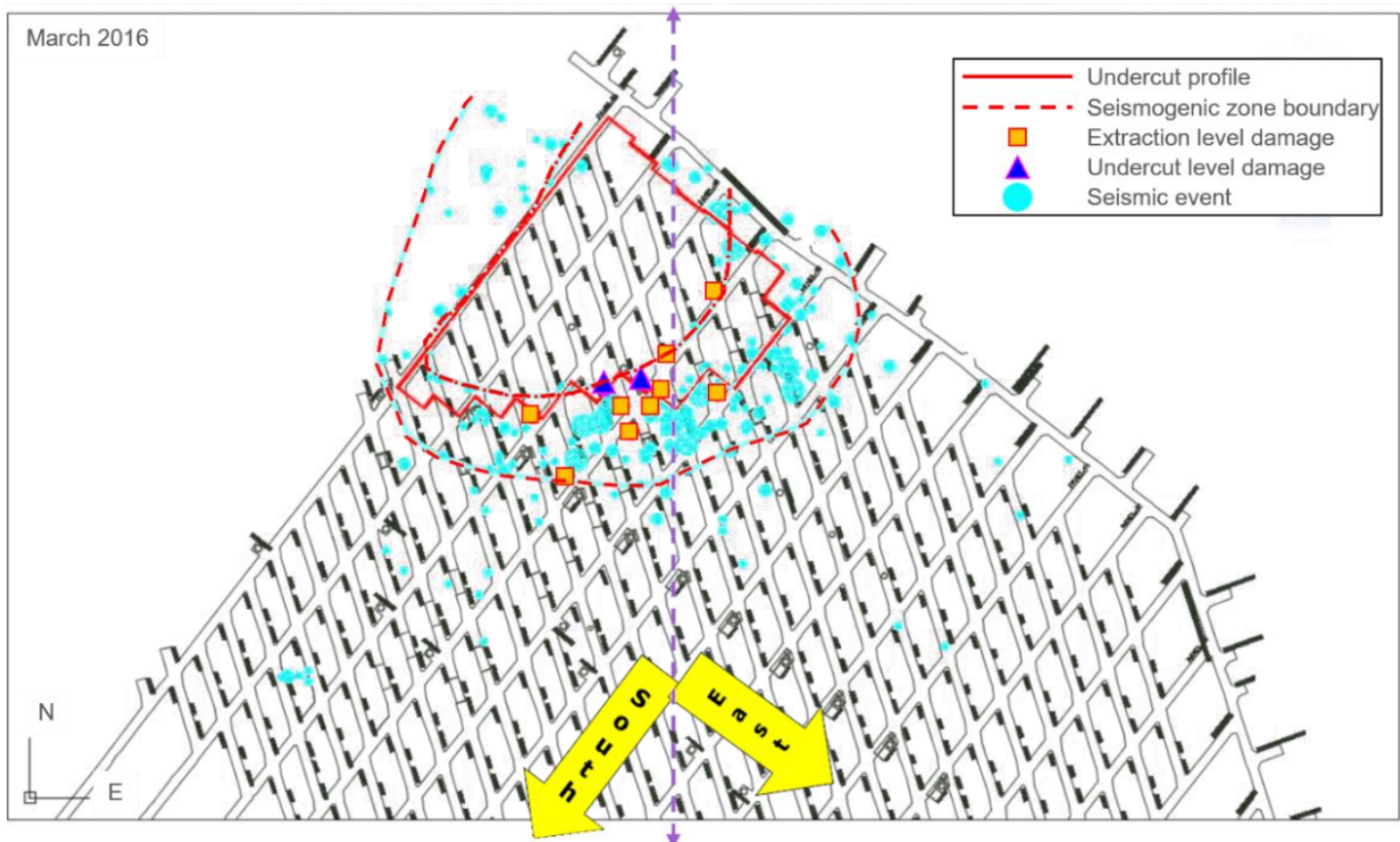

Figure 9 Plan view of seismicity around the extraction level, DMLZ in March 2016. Note the halo of activity in advance of the undercut, and the clustered distribution of damage

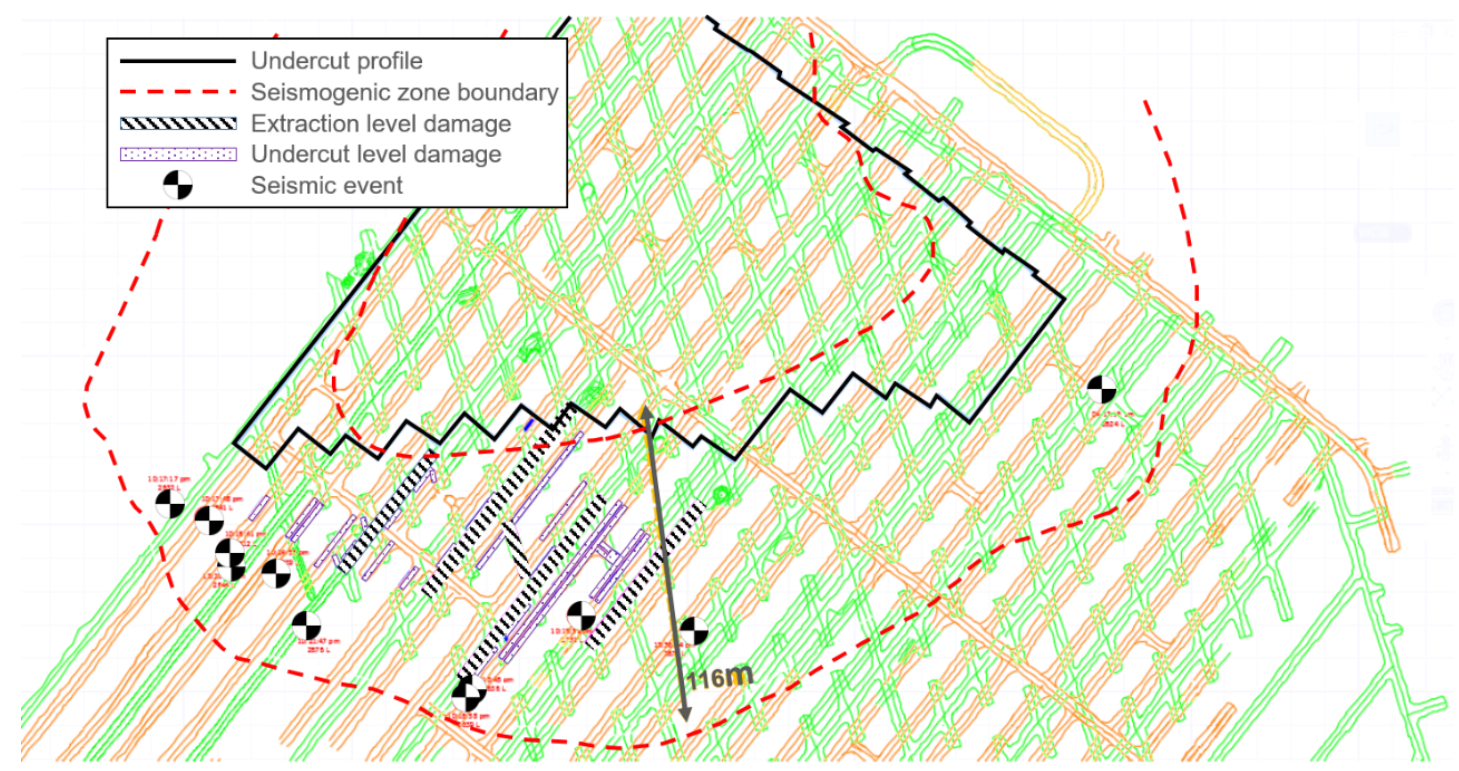

Figure 10 Damage mapping and plan view of seismicity around the extraction level, DMLZ. The 'beach ball' symbols are not intended to depict source mechanisms 


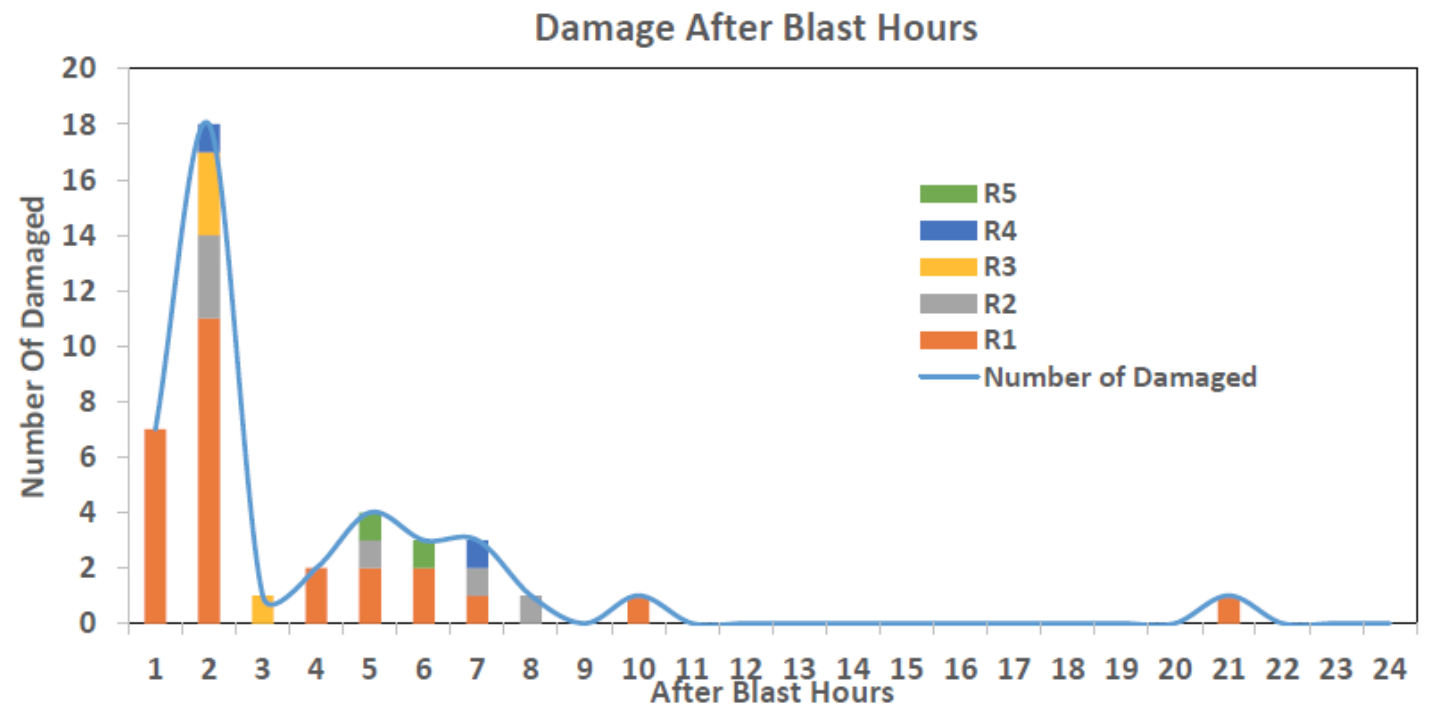

\begin{tabular}{|c|c|c|c|c|}
\hline $\begin{array}{c}\text { Damage } \\
\text { Scale }\end{array}$ & $\begin{array}{c}\text { Rock Mass } \\
\text { Damage }\end{array}$ & $\begin{array}{c}\text { Rock Support } \\
\text { Damage }\end{array}$ & $\begin{array}{c}\text { Typical } \\
\text { Event }\end{array}$ & $\begin{array}{c}\text { Depth of } \\
\text { Damage }\end{array}$ \\
\hline R1 & $\begin{array}{c}\text { No damage, } \\
\text { minor loose }\end{array}$ & No damage & $\begin{array}{c}\text { Onset of } \\
\text { Bulking }\end{array}$ & 0 \\
\hline R2 & $\begin{array}{c}\text { Minor damage, less } \\
\text { than } 1 \mathrm{t} \text { displaced }\end{array}$ & $\begin{array}{c}\text { Support system loaded, loose } \\
\text { in mesh, plated deformed }\end{array}$ & Bulking & $<0.25 \mathrm{~m}$ \\
\hline R3 & $\begin{array}{c}1-10 t \text { displaced } \\
\left(<10 \mathrm{~m}^{2} \text { area of damage }\right)\end{array}$ & Some broken support & $\begin{array}{c}\text { Shakedown or } \\
\text { Strainburst }\end{array}$ & $0.25-0.75 \mathrm{~m}$ \\
\hline R4 & $\begin{array}{c}10-100 t \text { displaced } \\
\left(<50 \mathrm{~m}^{2} \text { area of damage }\right)\end{array}$ & $\begin{array}{c}\text { Major damage to } \\
\text { support system }\end{array}$ & Strainburst & $0.75-1.5 \mathrm{~m}$ \\
\hline R5 & $\begin{array}{c}100+\mathrm{t} \text { displaced } \\
\left(>50 \mathrm{~m}^{2} \text { area of damage }\right)\end{array}$ & $\begin{array}{c}\text { Complete failure of } \\
\text { support system }\end{array}$ & Rockburst & $>1.5 \mathrm{~m}$ \\
\hline
\end{tabular}

Figure 11 Statistics of time after microseismic events and damage. Number of damage locations is plotted against time after blasts

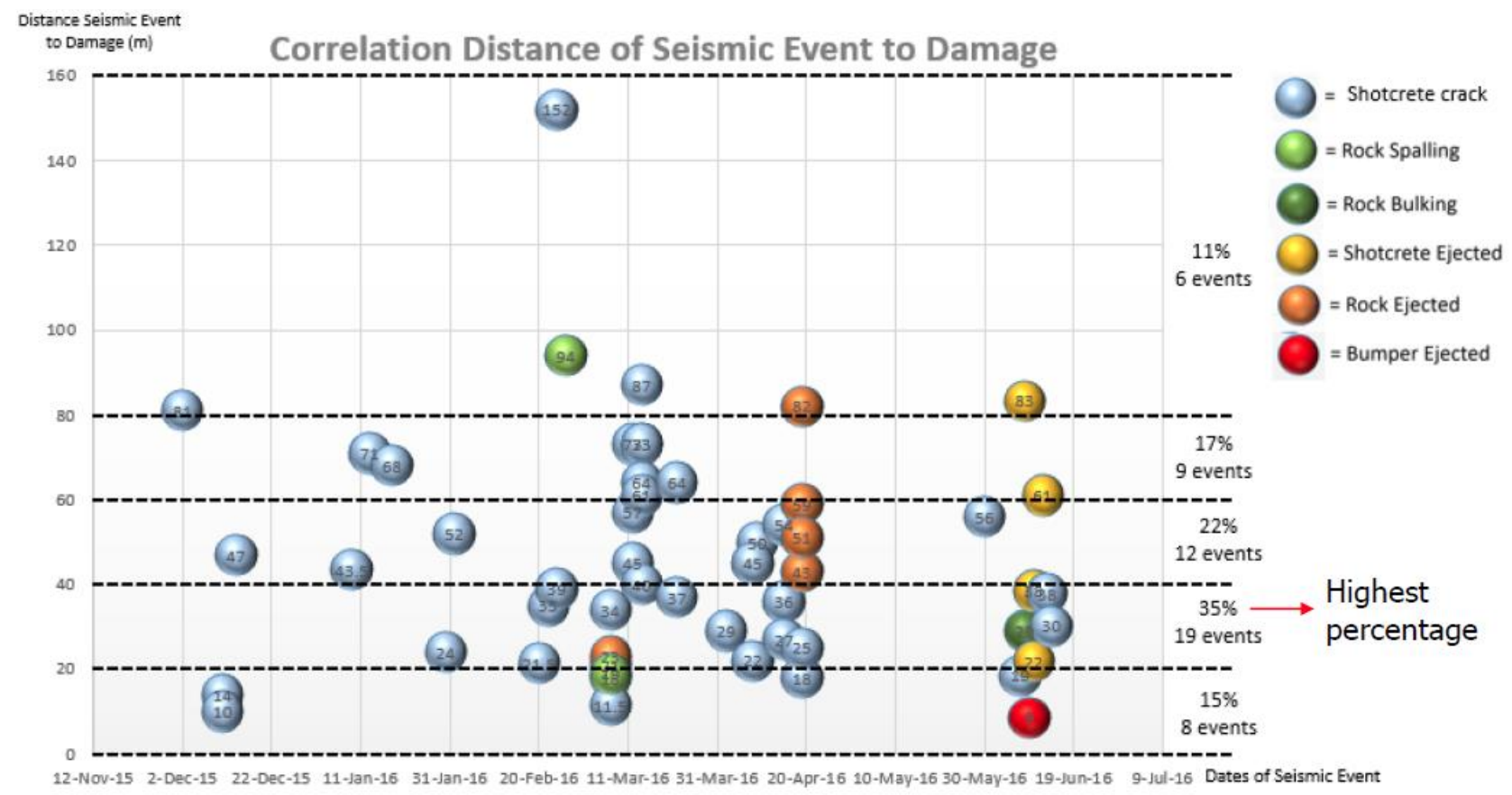

Figure 12 Correlation between distance from seismic events and damage 


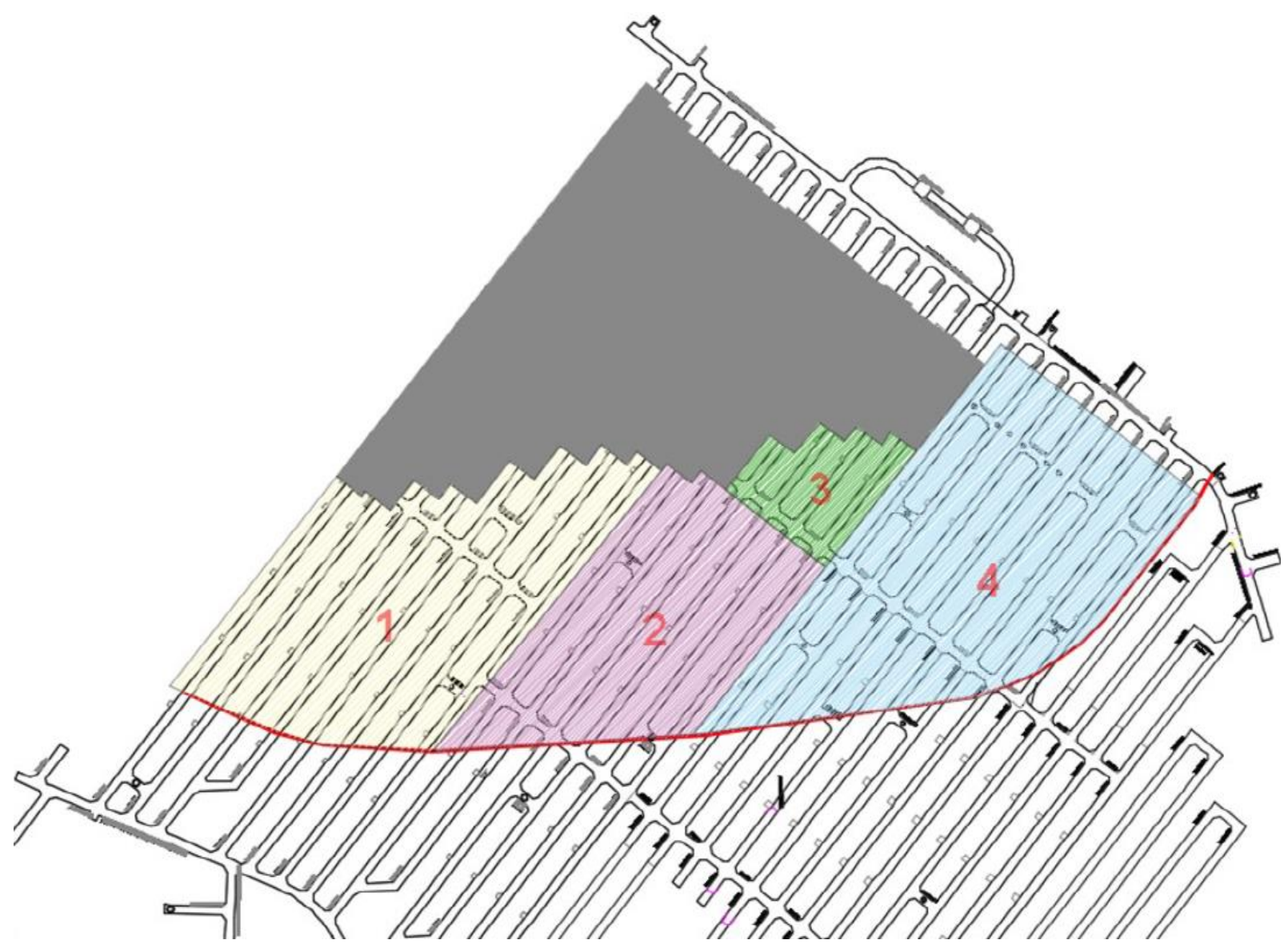

Figure 13 Near-cave seismic zones. The colours range in warmth from 'no-go' (red) to 'safe' (green). Numbers are simply identifiers from left to right (or west to east)

\subsection{Peak particle velocity scaling relationships}

Figure 14 presents a peak particle velocity (PPV)-distance-magnitude analysis of events which occurred in the DMLZ from March to October 2016. As expected, a generally increasing trend with magnitude is observed. The empirical formula is useful for determining expected PPV at different regions around the mine, especially at important infrastructure tunnels and access haulage ways. A $95 \%$ confidence fit is made to provide more conservative estimates of the PPV (Kaiser et al. 1996).

$$
\log (P P V)=1.01 \times M_{W}-1.02-1 \times \log (R)
$$

where $P P V$ is the peak particle velocity at a distance $R$ from an event of moment magnitude $M_{w}$. 


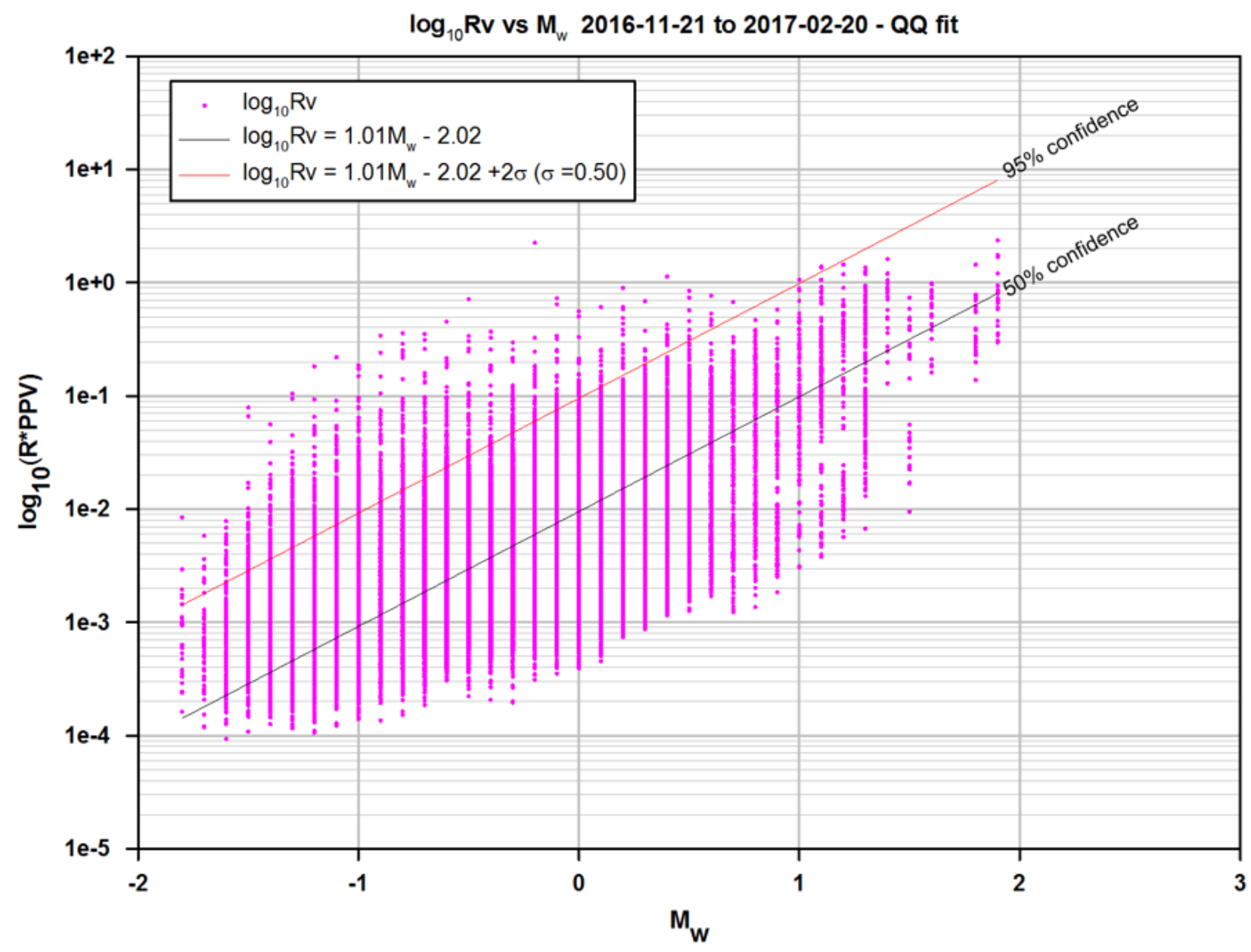

Figure 14 The PPV design scaling relation determined for the site. This relation can be used to estimate the peak particle velocity (peak ground velocity) around tunnel perimeters and throughout the rock mass, and can also be used in seismic hazard calculations

\section{Conclusions}

A key focus of the data analysis at the DMLZ to date has been to work towards the development of re-entry and exclusion protocols. A comprehensive descriptive record has been assembled of the evolution of the seismogenic zone (Figure 15) on a monthly basis. By combining this evolution with the zonation and damage mapping, hazard zones have been demarcated. When a seismic event exceeds a threshold (e.g., $M_{w}=-0.3$ ) or the rate of seismicity exceeds a certain limit (e.g., three threshold events per hour), the seismic hazard is considered as high. A protocol takes effect and the work force may be evacuated (or excluded) from a 'red zone' (Figure 16).

In the process of establishing data gathering and analysis procedures, the foundations have been laid for interpreting the physics of the rock mass response. The aim of this would be to understand the rock mass response to mining by understanding the evolution of stress in the rock and to manage it by optimising the support and blasting design. 


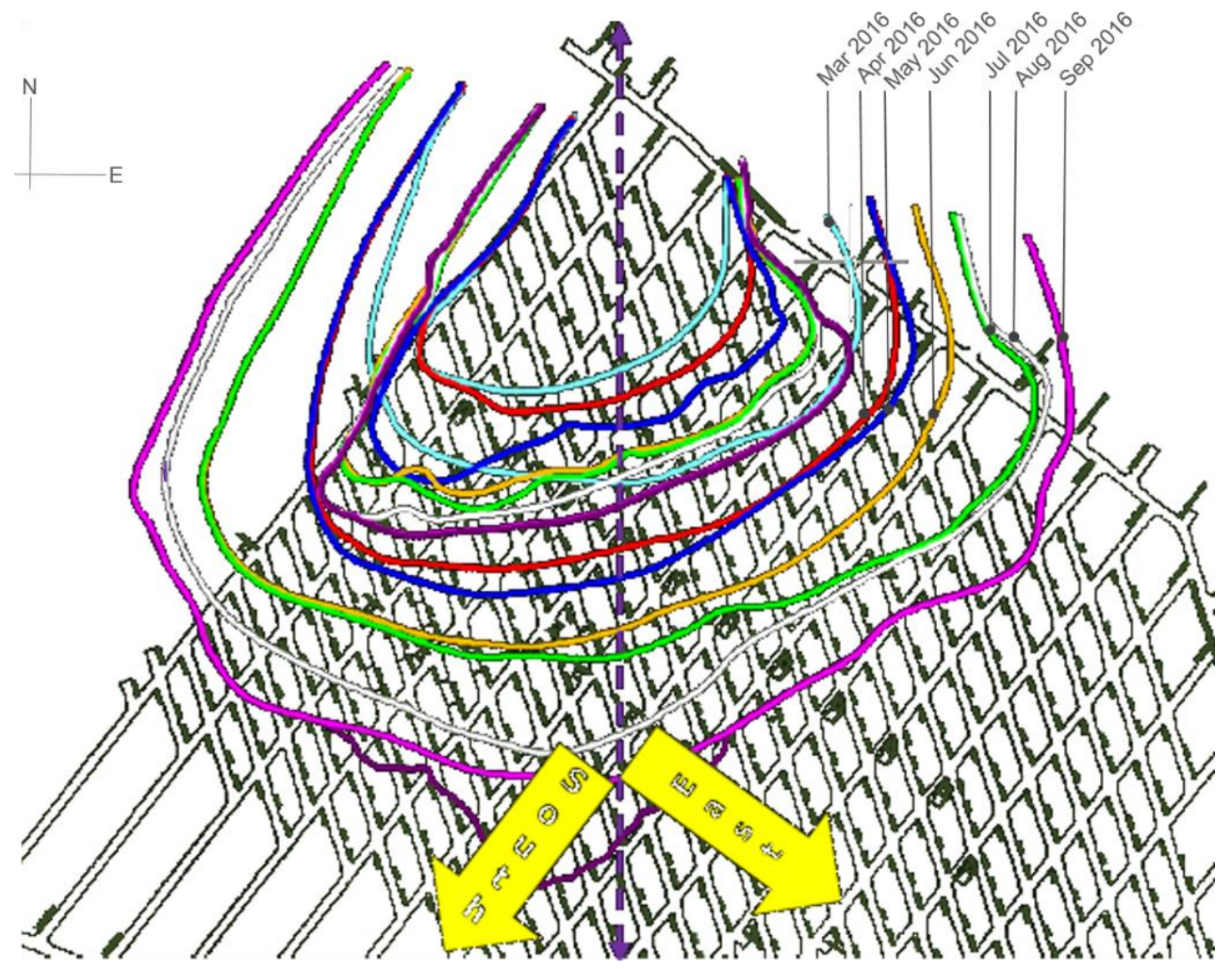

Figure 15 Summary of a timelapse sequence of the seismogenic zone development

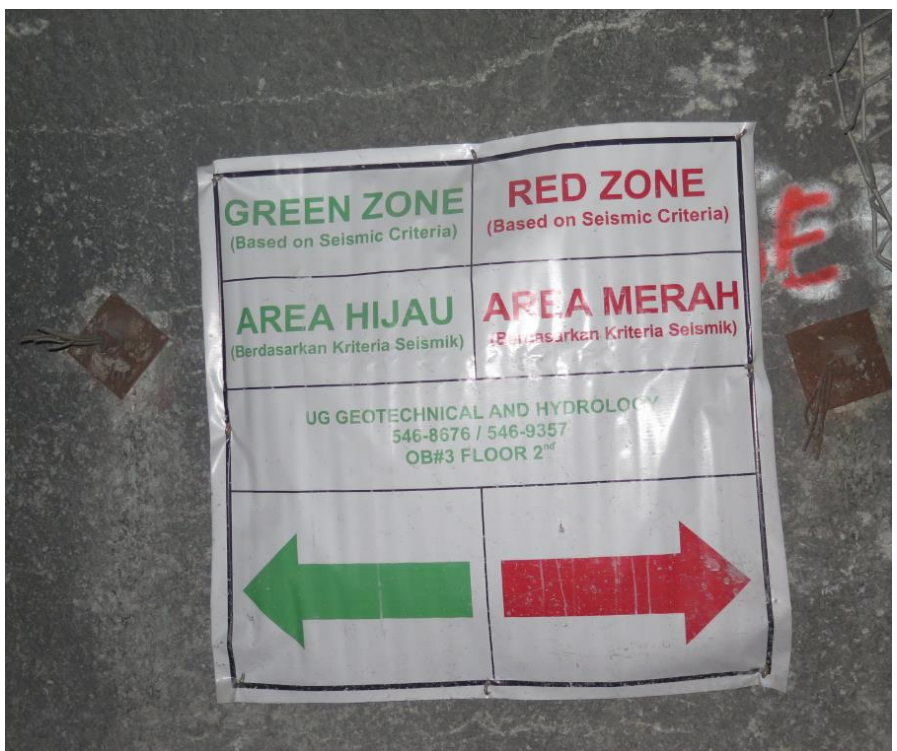

Figure 16 Indication underground at DMLZ of the different zones based on seismic hazard

\section{Acknowledgement}

The authors appreciate the authorisation from the senior management of PT Freeport Indonesia to publish this paper. 


\section{References}

Call \& Nicholas, Inc. 2009, Geomechanical Feasibility Study for DMLZ, report by Call \& Nicholas, Inc., Tucson.

Casten, T, Parinta, A \& Rumbino, H 2016, 'Deep Mill Level Zone - from feasibility to production', Proceedings of the Seventh International Conference \& Exhibition on Mass Mining, The Australasian Institute of Mining and Metallurgy, Melbourne, pp. 681-688.

Collins, DS, Toya, Y, Pinnock, I, Shumila, V \& Hosseini, Z 2014, '3D velocity model with complex geology and voids for microseismic location and mechanism', in M Hudyma \& Y Potvin (eds), Proceedings of the Seventh International Conference on Deep and High Stress Mining, Australian Centre for Geomechanics, Perth, pp. 681-688.

Kaiser, PK, McCreath, DR \& Tannant, DD 1996, Canadian Rockburst Support Handbook, Geomechanics Research Centre, Laurentian University, Sudbury.

Kurniawan, A, Sjadat, A \& Akhasyah, M 2016, 'Rehabilitation of the collapsed panel 1K north in the deep ore zone block cave mine', Proceedings of the Seventh International Conference \& Exhibition on Mass Mining, The Australasian Institute of Mining and Metallurgy, Melbourne, pp. 763-768.

Pinnock, I, Collins, DS, Toya, Y, Shumila, V \& Hosseini, Z 2016, 'Large event sequence analysis and 3D velocity models for seismic event location accuracy', Proceedings of the Seventh International Conference \& Exhibition on Mass Mining, The Australasian Institute of Mining and Metallurgy, Melbourne, pp. 879-884. 

and high-stress block cave Deep Mill Level Zone mine 